\title{
De haalbaarheid van een stepped care-interventie ter vermindering van de kwetsbaarheid van chronisch zieke werknemers
}

\author{
Ruben M. W. A. Drost - Aggie T. G. Paulus · Silvia M. A. A. Evers · Angelique E. de Rijk
}

Published online: 17 December 2019

(C) The Author(s) 2019

\begin{abstract}
Samenvatting
Inleiding Om de kwetsbaarheid van werknemers met chronische aandoeningen te verkleinen is een stepped care-interventie ontwikkeld, bestaande uit vier onderdelen: een e-health Werkscan met gepersonaliseerde feedback, met optioneel de keus om gebruik te maken van een informatieve online gids, een helpdesk en een Werkscan-gesprek met een arbeidsdeskundige. Doel van dit onderzoek was om belemmerende factoren voor deelname aan te wijzen en tevredenheid over deze interventie te evalueren.

Methoden De data werden verzameld door een Werkscan-gesprek af te nemen, naast aanvullende online vragenlijsten aan de start van het onderzoek en drie maanden erna. De deelnemers voldeden aan de volgende inclusiecriteria: tussen de 18 en 65 jaar oud, werkend (betaald werk en/of vrijwilligerswerk) en behorend tot de doelgroep mensen met chronische nieraandoeningen, sarcoïdose, neurofibromatose, chronische hoofdpijn, hiv en/of taaislijmziekte.

Resultaten De deelnemers $(n=84)$ hebben zeer beperkt gebruikgemaakt van de gids, helpdesk en het gesprek met een arbeidsdeskundige. De deelnemers
\end{abstract}

Dr. R. M. W. A. Drost (两) • Dr. A. T. G. Paulus .

Prof.dr.mr. S. M. A. A. Evers

Care and Public Health Research Institute (CAPHRI),

vakgroep Health Services Research, Maastricht University,

Maastricht, Nederland

r.drost@maastrichtuniversity.nl

Prof.dr.mr. S. M. A. A. Evers

Publieke Geestelijke Gezondheid, Centrum voor

Economische Evaluatie, Trimbos-instituut, Utrecht,

Nederland

Prof.dr A. E. de Rijk

Care and Public Health Research Institute (CAPHRI), vakgroep Sociale Geneeskunde, Maastricht University, Maastricht, Nederland die dit gesprek wel hadden beoordeelden het met een gemiddeld rapportcijfer van 8,6 .

Conclusie Om interventies voor kwetsbare werknemers te laten slagen moeten ze gefinancierd worden aangeboden, op maat worden gemaakt (tailored) en gericht (targeted) onder de aandacht worden gebracht.

Trefwoorden E-health · stepped care .

arbeidsparticipatie · inzetbaarheid $\cdot$ chronisch zieken

The feasibility of a stepped care intervention to reduce the vulnerability of chronically ill employees

\begin{abstract}
Introduction To reduce the vulnerability of employees with a chronic disease a 'stepped care' intervention was developed, consisting of four parts: an E-health 'Work scan' with personalized feedback and, optional, additional free choice to make use of an informative online guide, a helpdesk and a work interview with an occupational health expert. The aim of this study was to identify obstructive factors for participation and to evaluate satisfaction with this intervention.

Methods Data were collected through the Work scan and additional questionnaires at the start of the study and after three months. Participants met the following inclusion criteria: between 18 and 65 years old, working (paid work and/or voluntary work), belonging to the target group of people with chronic kidney disease, sarcoidosis, neurofibromatosis, chronic headache, HIV and/or cystic fibrosis.

Results Participants ( $n=84)$ made limited use of the guide, helpdesk and the option to talk with an occupational health expert. The participants who did see the expert assessed this with an average score of 8.6. Discussion It can be concluded that, in order for interventions for vulnerable employees to succeed, these
\end{abstract}


should be financially covered, tailored to individual needs and brought to the attention in a properly targeted manner.

Keywords E-health · stepped care · labour participation · employability $\cdot$ chronic disease

\section{Inleiding}

Van de Nederlandse beroepsbevolking hebben ruim 3 miljoen werknemers (dat is een op de drie) last van een of meer chronische aandoeningen. Ongeveer de helft van de werknemers met een chronische aandoening (49\%) geeft aan door de aandoening beperkt te worden bij het uitvoeren van het werk. Van alle werknemers geeft ruim vier op de tien aan in lichte mate beperkt te worden, en bijna $8 \%$ rapporteert een ernstige beperking [1]. De verwachting is dat de vergrijzing een belangrijk effect zal hebben op een toename van gezondheidsproblemen onder werkenden. Chronische aandoeningen komen vaker voor bij werkenden vanaf 45 jaar en werknemers met een chronische aandoening verzuimen meer [2]. De totale kosten van verzuim, de uitstroom uit arbeid in een arbeidsongeschiktheidsuitkering en de kosten van gezondheidszorg worden geschat op ruim 26 miljard euro [3].

Deze cijfers waren mede aanleiding voor het doen van onderzoek naar de mate van arbeidsparticipatie en de beleving daarvan onder acht groepen chronisch zieken waarover op dit gebied nog weinig bekend was. De conclusie van dit onderzoek onder 3.500 deelnemers die een vragenlijst invulden en 50 mensen die deelnamen aan diepte-interviews, was dat de groep zowel krachtig was als kwetsbaar. Krachtig vanwege de arbeidsparticipatie die (veel) hoger was dan verwacht en de positieve werkbeleving, kwetsbaar vanwege vermoeidheid en gezondheidsklachten bij werkenden en de problemen bij het vinden van werk [4].

In 2016 heeft de Sociaal-Economische Raad een advies uitgebracht gericht op het aan het werk krijgen en houden van mensen met een chronische ziekte [2]. Het onderwerp 'chronisch zieken en werk' staat dus al langere tijd hoog op de beleidsagenda van de overheid, werkgeversorganisaties, werknemersorganisaties en patiëntenorganisaties. Overeenkomend met dit advies heeft stichting OEK (Op Eigen Kracht aan het werk, een samenwerkingsverband van de Nierpatiënten Vereniging Nederland, de Sarcoïdose Belangenvereniging Nederland, de Nederlandse Vereniging van Hoofdpijnpatiënten, de Neurofibromatose Vereniging Nederland, de Hiv Vereniging Nederland en de Nederlandse Cystic Fibrosis Stichting) zich ten doel gesteld de arbeids- en sociale participatie onder hun achterban te bevorderen. Daartoe is een interventie ontwikkeld: een stepped care-interventie (getrapte zorg) met een e-healthcomponent en drie aanvullende optionele onderdelen voor werkenden met een chronische aandoening. Het doel van de interventie is dat de werkende zelf een actieve rol krijgt bij het organiseren van de combinatie 'participatie én omgaan met gezondheidsproblemen', en dat hierdoor de belasting tijdens het werken verlaagd en de belastbaarheid vergroot wordt.

Hoewel de interventie al vrij toegankelijk was voor de achterban van de eerdergenoemde patiëntenverenigingen, was er nog geen onderzoek gedaan naar deelname aan de interventie. In dit kader is de volgende samengestelde onderzoeksvraag geformuleerd: wat is de haalbaarheid van de stepped care-interventie in termen van deelname, tevredenheid en eventuele belemmerende factoren voor deelname?

\section{Methoden}

\section{Onderzoeksontwerp}

Het ging om een stepped care-interventie, die bestond uit een e-healthcomponent en drie optionele aanvullende interventies, te weten een informatieve online gids, een helpdesk en een gesprek met een door Stichting Blik op Werk gecertificeerde arbeidsdeskundige, die ook moest voldoen aan de registratie dan wel certificering van de beroepsgroep. Data werden verzameld door middel van het afnemen van online vragenlijsten aan de start van het onderzoek (T0) en achteraf na drie maanden (T1). Chronisch zieken konden deelnemen aan het onderzoek tussen 1 augustus 2016 en januari 2017. De laatste nameting vond plaats in april 2017.

Het protocol voor dit onderzoek, met daarin onder andere een beschrijving van de informed consentprocedure, dataverzameling en dataopslag, is beoordeeld door de METC van de Universiteit Maastricht (UM) en als niet-Wmo-plichtig geclassificeerd (referentie 2016/OEK-EVA).

\section{Deelnemers en werving}

Om inzichtelijk te kunnen maken welk deel van de gebruikers van de e-healthcomponent daadwerkelijk gebruik zou gaan maken van aanvullende interventieonderdelen, is de stepped care-interventie door middel van flyers, e-mailing, social media en verschillende andere kanalen extra onder de aandacht gebracht. De verantwoordelijkheid voor de werving van deelnemers lag in handen van de eerdergenoemde patiëntenverenigingen. Voor de werving van deelnemers was er geen contact tussen de auteurs van dit artikel en potentiële deelnemers. De deelnemers voldeden aan de volgende inclusiecriteria: tussen de 18 en 65 jaar oud, werkend (betaald werk en/of vrijwilligerswerk) en behorend tot de doelgroep mensen met chronische nieraandoeningen, sarcoïdose, neurofibromatose, chronische hoofdpijn, hiv en/of taaislijmziekte. Om in aanmerking te komen hoefden de deelnemers niet verplicht lid te zijn van een van de zes eerder genoemde patiëntenverenigingen. Personen die al eerder van het 
aanbod van OEK gebruik hadden gemaakt, werden uitgesloten van deelname.

De deelnemers ontvingen voorafgaand aan het onderzoek informatie over het doel ervan. Deelname was geheel vrijblijvend en deelnemers hadden te allen tijde de mogelijkheid om te stoppen.

\section{Interventie}

De interventie werd aangeboden via de website van OEK en bestond zoals gezegd uit vier onderdelen. Deze onderdelen kunnen als een vorm van steppedcare worden beschouwd, waarbij opgeschaald kon worden. De interventie varieerde van een laagdrempelige interventie die vooral op het verkrijgen van inzicht was gericht, tot een intensief coachingsgesprek met een arbeidsdeskundige. De deelnemer kon dus zelf 'opschalen'. Iedere deelnemer aan de interventie werd eerst gevraagd om de Werkscan in te vullen via een link naar de website van het Arbeidsdeskundig Kennis Centrum. De Werkscan beoogt de duurzame inzetbaarheid van werknemers te bevorderen [5]. Een belangrijke component hierin is de workability index, een gevalideerde vragenlijst waarmee werkvermogen wordt gemeten [6]. Met behulp van deze scan kreeg de deelnemer een beeld van zijn of haar balans tussen enerzijds werk en anderzijds persoonlijke belastbaarheid (bepaald door zowel fysieke, mentale als sociale determinanten). Na invulling van de Werkscan ontving de deelnemer per e-mail het resultaat met betrekking tot zijn of haar werkvermogen. Dit kon zijn: uitstekend, goed, matig of slecht. Vervolgens kregen de deelnemers adviezen waarin ook aandachtspunten met betrekking tot hun inzetbaarheid waren opgenomen. Tevens werd meer concreet ingegaan op de gebieden waarin actie ondernomen kon worden om het werkvermogen te verbeteren. Dit betreft de gebieden gezondheid, leefstijl, werk, werk-privébalans, scholing/opleiding, loopbaanontwikkeling en -mobiliteit, en zelfredzaamheid.

Naast deze adviezen en aandachtspunten op basis van de Werkscan kon de deelnemer via diezelfde website en naar eigen keuze toegang krijgen tot interventieonderdelen 1, 2 en 3 :

1. de Gids, waarbij via de website digitaal informatie werd aangeboden met betrekking tot gezondheid, leefstijl, werk, werk-privébalans, scholing/ opleiding, loopbaanontwikkeling, loopbaanmobiliteit en zelfredzaamheid;

2. de Helpdesk, waarbij een ervaringsdeskundige aan de hand van motivational interviewing de deelnemer stimuleerde om gedachten over het verbeteren van arbeidsparticipatie om te zetten naar acties ten behoeve hiervan;

3. het Werkscan-gesprek, waarbij het gesprek met een arbeidsdeskundige verdiepende inzichten kon opleveren en een concreet plan van aanpak kon worden opgesteld.

De Werkscan en de interventieonderdelen 1 en 2 waren gratis voor de deelnemers. Alleen voor onderdeel 3 moest betaald worden: $€ 102,85$ inclusief btw voor het gesprek via Skype of Facetime, met aanvullend hetzelfde bedrag voor een verslag en meerkosten indien het gesprek face-to-face werd gevoerd. De deelnemers betaalden dit bedrag zelf of vroegen hun werkgever dit te doen. Op de website stonden tips om de werkgever om betaling te vragen zonder privacygevoelige informatie over de aandoening uit te wisselen.

\section{Dataverzameling}

Deelnemers vulden op T0 eerst een online vragenlijst van de UM in. Voordat ze dat deden kregen ze informatie over het doel van het onderzoek, de dataopslag en hun rechten. Doorgaan na deze informatiepagina gold als informed consent. De deelnemers konden op dat moment, maar ook later besluiten de deelname stop te zetten. De vragenlijst bevatte items die niet in de Werkscan zijn opgenomen, maar wel van belang waren voor de evaluatie. Voor een eventuele aanvullende effectiviteits- en kostenanalyse bij voldoende deelname waren ook vragen opgenomen over het gebruik van de gezondheidszorg, de kwaliteit van leven, productiviteit op werk, werkbeleving,
Tabel 1 Variabelen die via de UM-vragenlijst zijn bevraagd

\begin{tabular}{|c|c|}
\hline Variabele & (Onderdeel van) instrument \\
\hline Inclusie (op T0) & Eigen \\
\hline Werkbeleving & Utrecht Work Engagement Scale (UWES-9) [14] \\
\hline Duurzame inzetbaarheid & Maastricht Instrument for Sustainable Employability NL (MAISE-NL) \\
\hline Productiviteit & iMTA Productivity Cost Questionnaire (iPCQ) [15] \\
\hline $\begin{array}{l}\text { Gebruik van de gezond- } \\
\text { heidszorg }\end{array}$ & Trimbos and iMTA questionnaire on Costs associated with Psychiatric illness (TiC-P) \\
\hline Activiteiten & $\begin{array}{l}\text { Eigen - gezondheidszorg, leefstijl, werkomstandigheden, sociale steun, werk-privébalans, } \\
\text { cursus en opleiding, loopbaanontwikkeling, loopbaanmobiliteit }\end{array}$ \\
\hline \multirow{2}{*}{$\begin{array}{l}\text { Gezondheid/kwaliteit } \\
\text { van leven }\end{array}$} & EuroQol Five Dimensions Five Level Questionnaire (EQ-5D-5L) [16] \\
\hline & EuroQol Visual Analog Scale (EQ VAS) [16] \\
\hline Eigen effectiviteit & General Self-Efficacy Scale (GSE) [17] \\
\hline Slotvragen & Eigen \\
\hline
\end{tabular}


Figuur 1 Routings van deelnemers op TO (0 maanden) en T1 (3 maanden)

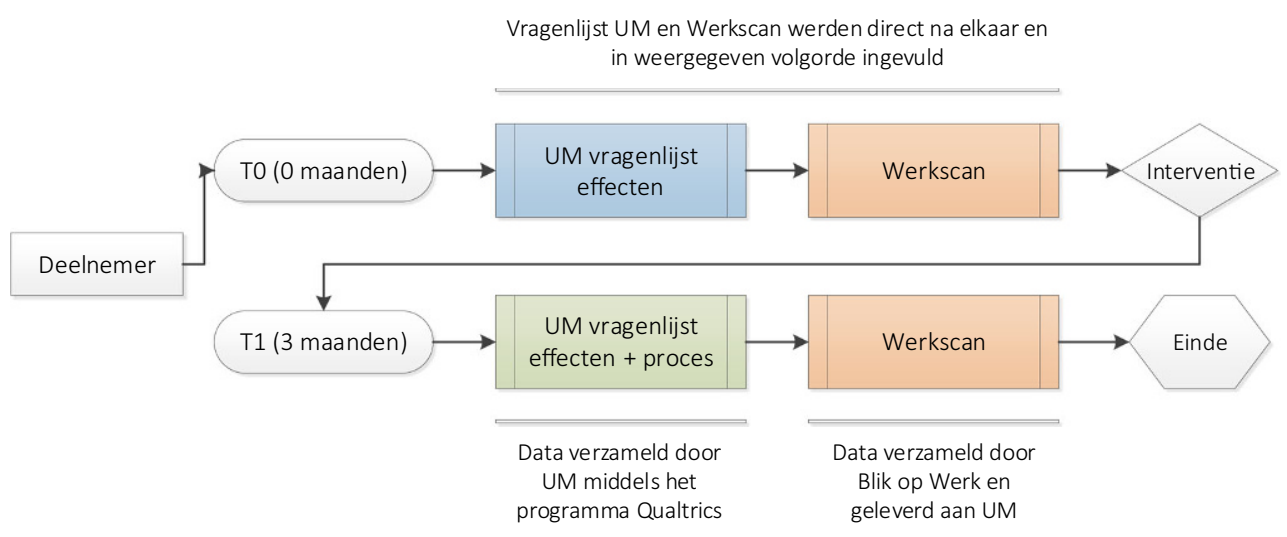

inzetbaarheid en eigen effectiviteit. Variabelen die via de UM-vragenlijst zijn gemeten staan in tab. 1. De vragenlijst is op te vragen bij de eerste auteur.

De UM-vragenlijst werd afgenomen via het surveyprogramma Qualtrics [7]. Voorafgaand aan het onderzoek is deze vragenlijst door middel van een pilotonderzoek geoptimaliseerd. Antwoorden van deelnemers werden automatisch opgeslagen en waren zichtbaar voor de onderzoekers van de UM. Na het invullen van de UM-vragenlijst kregen de deelnemers toegang tot de online Werkscan. Op basis van de antwoorden in de Werkscan ontvingen de deelnemers een advies en kregen ze toegang tot de interventie. Werkscandata werden automatisch opgeslagen door Stichting Blik op Werk, die de gegevens leverde aan de UM-onderzoekers. In zowel de UM-vragenlijst als de Werkscan vulden deelnemers hun e-mailadres in. Dit was van belang voor a) het koppelen van data van de UMvragenlijst en de Werkscan en b) het benaderen van deelnemers voor de nameting. De procedure op T1 was hetzelfde als op T0, met als verschil dat de UMvragenlijst op $\mathrm{T} 1$ werd uitgebreid met vragen die nodig waren voor de procesevaluatie (fig. 1).

Gegeven de geringe deelname en hoge drop-out tijdens het verloop van het onderzoek is de analyse beperkt tot beschrijvende statistiek en beschrijvende kwalitatieve evaluaties.

\section{Resultaten}

\section{Aantal deelnemers en achtergrondkenmerken}

Van de 160 deelnemers die op T0 de vragenlijst volledig hadden ingevuld vulden er 84 ook de T0 Werkscan in (fig. 2). In totaal gaven 149 deelnemers hun e-mailadres op, zodat ze benaderd konden worden voor de T1-meting. Uiteindelijk waren 55 deelnemers (34\%) bereid en in staat om de T1-vragenlijst in te vullen. Van hen hadden 36 deelnemers al eerder op T0 ook de Werk-

scan ingevuld.

Van de 36 deelnemers waren er 21 (58\%) man. Het merendeel was medewerker met een vast dienstver- band ( $n=30,83 \%$ ). De achtergrondkenmerken van de deelnemende groep staan in tab. 2 .

\section{Deelnemers en ervaringen per interventieonderdeel}

\section{De Werkscan}

Van de 55 deelnemers op T1 hadden er 36 op T0 de Werkscan volledig ingevuld. Aangezien de interventies gids, helpdesk en het Werkscan-gesprek met arbeidsdeskundige beschikbaar werden gesteld via de website van Stichting OEK (inmiddels niet meer online) en deze drie interventies werden aangeboden nadat de Werkscan was ingevuld, was de kans op gebruik van een of meer van deze interventies groter als de Werkscan ook daadwerkelijk werd ingevuld.

\section{De gids}

Van de 36 deelnemers op T1 gaf één deelnemer aan een keer van de gids gebruik te hebben gemaakt. Deze deelnemer raadpleegde de tabbladen 'Gezondheid', 'Leefstijl' en 'Werk'. Deze deelnemer kon zich niet voor de geest halen welke delen hij/zij nuttig vond en waardeerde de gids met een ' 5 '.

\section{De helpdesk}

De 36 deelnemers op T1 geven allen aan geen gebruik van de helpdesk te hebben gemaakt. Van hen gaven 17 deelnemers aan wel op de hoogte te zijn van de mogelijkheid om de helpdesk te bellen, maar geen interesse te hebben. Twee deelnemers waren hier nog niet aan toe gekomen. Zes deelnemers wisten niet van het bestaan van de helpdesk af, maar wilden daar alsnog gebruik van maken. Elf deelnemers gaven ook aan niet van het bestaan van de helpdesk af te weten en hadden er geen interesse in.

\section{Werkscan-gesprek met arbeidsdeskundige}

Van de 36 deelnemers op $\mathrm{T} 1$ gaven vijf deelnemers aan een Werkscan-gesprek met een arbeidsdeskundige te hebben gehad. Bij vier deelnemers was dit gesprek door hun werkgever betaald. In één geval is er niet betaald. Vier personen gaven aan één gesprek te hebben gehad en één deelnemer had drie gesprekken met een arbeidsdeskundige. Alle vijf hebben ze concrete 
Figuur 2 Stroomschema van deelnemers binnen het OEK EVA-onderzoek. $\mathrm{TO}=$ meetmoment aan de start, $\mathrm{T} 1=$ meetmoment na drie maanden. Uiteindelijk is de interventiedeelname en zijn de effecten op en kosten voor de groep van $(20+16=) 36$ deelnemers onderzocht (zie de groene velden)

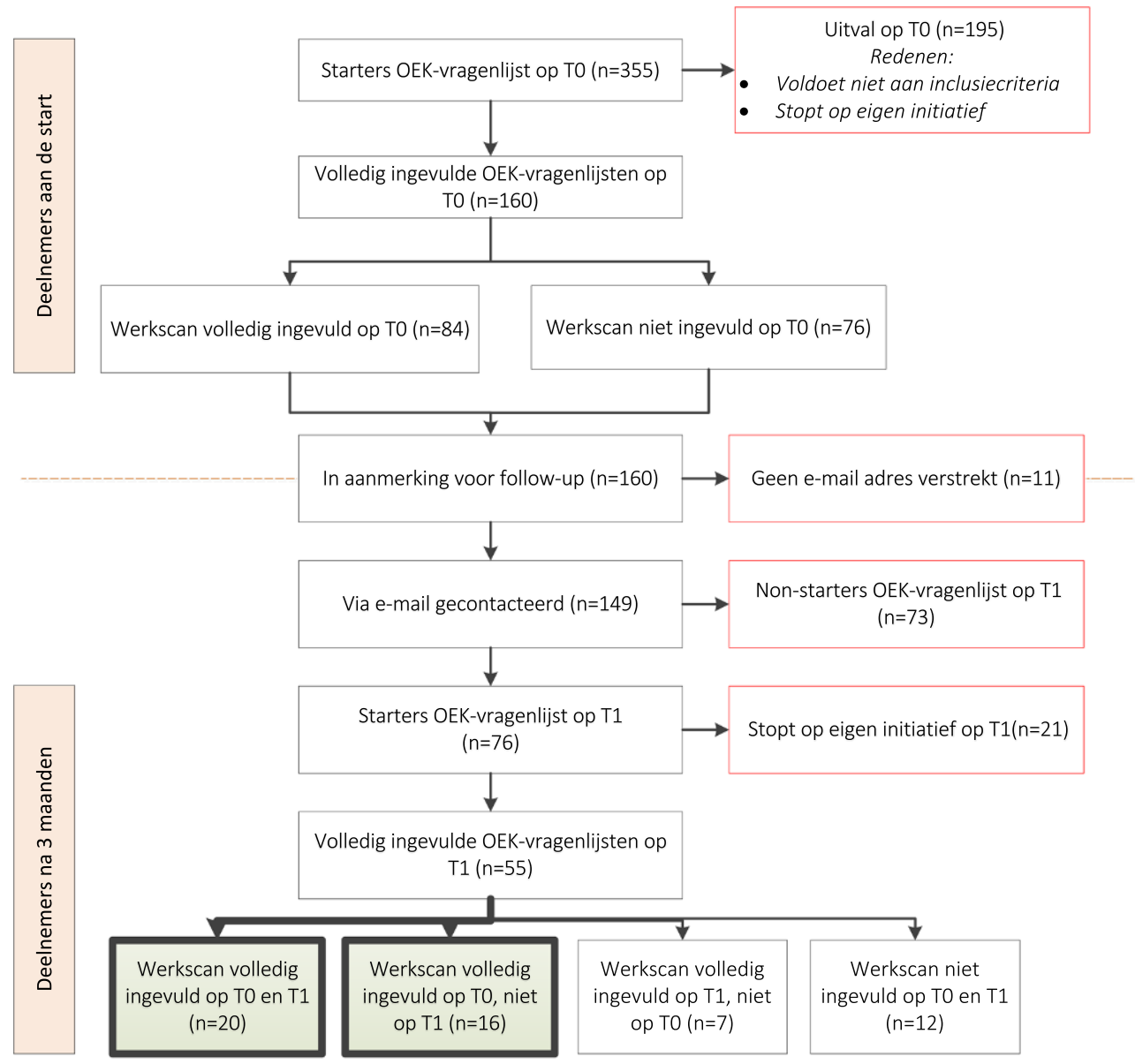

afspraken gemaakt met de arbeidsdeskundige, die ze zelf als volgt samenvatten:

1. 'Ben nu werkzoekende en heb 10 maart afspraak met UWV-arts. Ontslag gekregen omdat ik te vaak uitviel met migraine.'

2. 'Eventueel rustdag tussen werkdagen, pauzes nemen, bij vermoeidheid meer backoffice in plaats van frontoffice, ruilen met werkzaamheden collega andere polikliniek.'

3. 'Minder uren werken en minder druk op het werk.'

4. 'Urenbeperking en de belastbaarheid van de taken.'

5. 'Van een fulltimewerkweek (40 uur) naar een parttimewerkweek per 1 april, daarbij gebruikmakend van de PAS-regeling [Partiële Arbeidsparticipatie Senioren].'

De vijf deelnemers waardeerden het Werkscan-gesprek als volgt: één deelnemer gaf een 7 , één een 8 , twee een 9 en één een 10. Alle vijf waren ze tevreden over de mate van de eigen inbreng tijdens het gesprek.

Van de overige 31 gaven achttien deelnemers aan geen interesse te hebben. Twee deelnemers hadden wel behoefte aan een gesprek, maar wilden dit niet zelf betalen en konden niemand vinden die het voor hen wilden betalen. Drie deelnemers gaven aan niet van het bestaan van het Werkscan-gesprek af te weten, maar wilden hier alsnog gebruik van maken. Zeven deelnemers wisten ook niet van het bestaan van de helpdesk en gaven aan hier geen interesse in te hebben. Eén deelnemer gaf aan dat de reisafstand een belemmering vormde.

\section{Beschouwing}

Doel van dit onderzoek was om de deelname aan verschillende onderdelen binnen de interventie en de tevredenheid over de losse interventieonderdelen te evalueren. Op basis van de resultaten kan geconcludeerd worden dat relatief weinig deelnemers ervoor kozen om gebruik te maken van de optionele aanvullende interventieonderdelen. De deelnemers hebben geen gebruikgemaakt van de helpdesk en het aantal deelnemers dat van de gids en het Werkscan-gesprek met arbeidsdeskundige gebruik heeft gemaakt is zeer beperkt. De blootstelling aan de interventie was dus beperkt. Daarnaast gaf een klein aantal deelnemers aan niet op de hoogte te zijn geweest van de mogelijkheid om gebruik te maken van de aanvullende interventieonderdelen gids, helpdesk en Werkscan-gesprek met arbeidsdeskundige. Bovendien gaven enkele deelnemers aan dat de kosten van het gesprek de reden vormden om het gesprek niet aan te gaan.

Opvallend is dat de deelnemers die het Werkscangesprek met arbeidsdeskundige wél hebben gehad, 
Tabel 2 Achtergrondkenmerken van de deelnemers $(n=36)$

\begin{tabular}{l|l|c|}
\hline Item & Man & $21(58 \%)$ \\
\hline Leeftijd & & $47,7(\mathrm{sd}=10,6)$ \\
\hline Burgerlijke status & Alleenstaand & $12(33 \%)$ \\
\hline & Gehuwd/samenwonend met thuiswonende kinderen & $12(33 \%)$ \\
\hline Hoogst genoten onderwijs & Gehuwd/samenwonend zonder thuiswonende kinderen & $12(33 \%)$ \\
\hline & Basisonderwijs & $1(3 \%)$ \\
\hline & Vmbo (lbo/mavo) & $3(8 \%)$ \\
\hline & Havo/vwo & $2(6 \%)$ \\
\hline Soort dienstverband & Mbo & $13(36 \%)$ \\
\hline & Hbo & $13(36 \%)$ \\
\hline Leidinggevende functie & Wetenschappelijk onderwijs (universiteit) & $4(11 \%)$ \\
\hline Jaren in functie & Medewerker met tijdelijk dienstverband & $2(6 \%)$ \\
\hline Uren werkzaam per week & Medewerker met vast dienstverband & $30(83 \%)$ \\
\hline Contracturen per week & Zzp'er/freelancer & $4(11 \%)$ \\
\hline & Ja & $11(31 \%)$ \\
\hline & & $11,7(\mathrm{sd}=9,8)$ \\
\hline
\end{tabular}

dit als zeer goed beoordeelden. Ze gaven gemiddeld een 8,6 voor dit interventieonderdeel, kregen genoeg ruimte voor hun eigen inbreng en hebben concrete afspraken gemaakt om verdere stappen te zetten om de werksituatie te verbeteren. Dit impliceert dat er in tijden van toenemende digitalisering van zorg en ondersteuning nog voldoende ruimte moet zijn voor persoonlijk contact.

\section{Methodologische reflectie en implicaties voor toekomstig onderzoek}

Een sterk punt van dit evaluatieonderzoek was dat het zich richtte op een relatief onontgonnen onderzoeksveld. Hoewel er al diverse ondersteuningsmogelijkheden zijn voor kwetsbare werknemers, wordt er nog te weinig onderzoek gedaan naar het gebruik en de gebruikerservaringen van dergelijke vormen van ondersteuning. Dit onderzoek was een eerste verkenning van de uitwerking van een stepped-care aanpak in de praktijk en was zo opgezet dat afzonderlijke interventieonderdelen geëvalueerd konden worden.

De belangrijkste beperking van dit onderzoek was het kleine aantal deelnemers. Aan het begin van het waren er weinig deelnemers en gedurende het onderzoek was de drop-out hoog, waardoor het niet verantwoord was om aanvullende analyses, zoals (kosten)effectiviteitanalyses uit te voeren. Door de hoge drop-out was het ook niet verantwoord om data aan de hand van imputatie te simuleren; een analyse op basis van een grote hoeveelheid gesimuleerde data zou tot bias in de resultaten hebben geleid.

Voor het kleine aantal deelnemers zijn enkele mogelijke verklaringen. Ten eerste hadden de onderzoekers slechts een beperkte invloed op de werving van potentiële deelnemers. De verantwoordelijkheid voor werving was in handen van een externe partij. De onderzoekers hebben wel herhaaldelijk ideeën aangeboden om de werving te bevorderen, die de externe partij meestal ook heeft uitgevoerd (e-mailing, flyeren, enzovoort).

Ten tweede had het onderzoek te kampen met een aanzienlijke uitval. Dit is een erkend probleem bij onderzoek naar interventies met een e-healthcomponent [8-10]. Slechts 55 van de 160 deelnemers waren bereid en/of in staat om na drie maanden de tweede en laatste UM-vragenlijst in te vullen, van wie er 36 al eerder de Werkscan hadden ingevuld. Mogelijk heeft ook de geringe belastbaarheid van de doelgroep te maken met de loss to follow-up. Een verzoek of herinnering om de Werkscan in te vullen via de reguliere post of per telefoon was omwille van privacyredenen niet mogelijk.

Ten derde, aangezien het gebruik van de Werkscan alleen te weinig informatie voor het onderzoek zou opleveren, was het noodzakelijk om een complementaire vragenlijst aan de Werkscan te koppelen. Deze UM-vragenlijst, die voorafgaand aan de Werkscan werd afgenomen, was zo geconstrueerd dat de inhoudelijke overlap met de Werkscan tot een minimum was beperkt. Desondanks was de helft van de deelnemers niet bereid en/of in staat om na afloop van het invullen van de UM-vragenlijst ook de Werkscan in te vullen. Een mogelijke verklaring hiervoor is dat deelnemers het invullen van zowel de UM-vragenlijst als de Werkscan op zowel T0 als T1 als te belastend ervaarden. Onderzoek op basis van kwalitatieve dataverzamelingsmethoden die meer diepgang bieden, zoals interviews en focusgroepen, biedt de mogelijkheid om dergelijke onderliggende factoren en verkla- 
ringen voor de beperkte deelname aan interventieonderdelen in beeld te brengen.

De beperkingen van dit onderzoek zouden ondervangen kunnen worden door verschillende maatregelen om het aantal deelnemers te vergroten en de belasting per deelnemer te verkleinen: 1) de uitvoerend onderzoeker zou tijdens de werving van deelnemers een directe rol en verantwoordelijkheid moeten hebben; 2) de uitvoerend onderzoeker zou voor communicatie met (potentiële) deelnemers naast e-mail toegang moeten hebben tot andere kanalen; 3 ) per meetmoment zou één vragenlijst gebruikt moeten worden, waarin alle relevante vragen zijn opgenomen die nodig zijn voor de dataverzameling; en 4) het aantal vragen per meetmoment zou beperkt moeten zijn. Het is verder van belang om een eigen vragenlijst met het oog op de deelnemers via een pilotonderzoek te testen op taalgebruik, en de belasting voor deze kwetsbare groep zo veel mogelijk te beperken. Door de eindgebruikers - in veel gevallen patiënten - daarbij te betrekken wordt de kans vergroot dat het onderzoek aansluit bij hun behoeften.

Wanneer het gewenste deelnemersaantal wordt bereikt, zouden de langetermijneffecten met betrekking tot kwaliteit van leven, veranderingen in zorgkosten, kosten van verzuim en van presenteïsme (verminderde productiviteit bij aanwezigheid) onderzocht kunnen worden. Om het gewenste deelnemersaantal voor een (kosten)effectiviteitsanalyse te bepalen moet voorafgaand aan het onderzoek een poweranalyse worden uitgevoerd. Met behulp van zo'n analyse worden de steekproefgrootte en de haalbaarheid van inclusie bepaald aan de hand van een minimaal klinisch relevant verschil.

\section{Implicaties voor de praktijk}

De resultaten van dit onderzoek onderstrepen het belang van targeting van interventies die mensen met een chronische aandoening aan het werk moeten houden (doelgroepbepaling en -benadering), tailoring van deze interventies (maatwerk) en de financiering ervan [11, 12]. Vooral toegang tot arbeidsdeskundigen zou bij de achterban van de patiëntenverenigingen meer onder de aandacht gebracht moeten worden, omdat de op maat gemaakte adviezen van de arbeidsdeskundigen als zeer goed werden beoordeeld. Daarnaast is het belangrijk om meer mogelijkheden te scheppen voor de financiering van dit gesprek, aangezien een aantal deelnemers het gesprek met de arbeidsdeskundige om financiële redenen niet aanging. In een situatie waarin bijna de helft van de beroepsbevolking wel vragen over arbeid en gezondheid kan hebben, maar geen toegang tot een bedrijfsarts heeft, ontstaat er ongelijkheid wat betreft de toegang tot begeleiding. Werknemers met chronische ziekten zijn bovendien vaak ontevreden over de begeleiding door hun bedrijfsarts, mede omdat veel bedrijfsartsen niet op de hoogte zijn van de specifieke chronische aandoeningen en het effect daarvan op het dagelijks leven. Daarom is er behoefte aan begeleiding door andere experts $[4,13]$. Dit alles pleit voor het wegnemen van de drie belemmeringen problemen met targeting, tailoring, financiering - bij toegang tot arbeidsdeskundigen.

Dankbetuiging De auteurs zijn een aantal organisaties erkentelijk voor de financiering (Arbeidsdeskundig Kennis Centrum), werving van deelnemers (Stichting Op Eigen Kracht) en levering van Werkscan-gegevens (Blik op Werk) ten behoeve van de evaluatie van de interventie. Daarnaast danken zij de deelnemers van dit onderzoek.

Open Access This article is licensed under a Creative Commons Attribution 4.0 International License, which permits use, sharing, adaptation, distribution and reproduction in any medium or format, as long as you give appropriate credit to the original author(s) and the source, provide a link to the Creative Commons licence, and indicate if changes were made. The images or other third party material in this article are included in the article's Creative Commons licence, unless indicated otherwise in a credit line to the material. If material is not included in the article's Creative Commons licence and your intended use is not permitted by statutory regulation or exceeds the permitted use, you will need to obtain permission directly from the copyright holder. To view a copy of this licence, visit http://creativecommons. org/licenses/by/4.0/.

\section{Literatuur}

1. TNO. Nederlandse Enquête Arbeidsomstandigheden. Hoofddorp: TNO;2011.

2. SER. Werk: van belang voor iedereen. Den Haag: SociaalEconomische Raad;2016.

3. Vroome EM de, Uegaki K, Ploeg CP van der, Treutlein DB, Steenbeek R, Weerd M de, et al. Burden of sickness absence due to chronic disease in the Dutch workforce from 2007 to 2011. JOccup Rehabil. 2015;25(4):675-84.

4. Klabbers G, Rooijackers B, Goertz G, Rijk A de. Krachtig en kwetsbaar: onderzoek naar de ervaringen met arbeidsparticipatie en sociale participatie van mensen met chronische ziekten en beperkingen. Maastricht: MaastrichtUniversity; 2014.

5. AKC. Hoe werkt deWerkscan? Zoetermeer: Arbeidsdeskundig Kennis Centrum; 2015.

6. Ilmarinen J. The Work Ability Index (WAI). Occup Med. 2007;57:160.

7. Qualtrics. https://www.qualtrics.com/.

8. Eysenbach G. The law of attrition. J Med Internet Res. 2005;7(1):e11.

9. Smit ES, Evers SM, Vries H de, Hoving C. Cost-effectiveness and cost-utility of Internet-based computer tailoring for smoking cessation. J Med Internet Res. 2013;15(3):e57.

10. Webb TL. Commentary on Shahab \& McEwen (2009): understanding and preventing attrition in online smoking cessation interventions: a self-regulatory perspective. Addiction. 2009;104(11):1805-6.

11. Genabeek J van, Noben C, Rooijackers B, Bakhuys-Roozeboom M, Huijs J, Oude HengelK, etal. Biedtinzicht uitzicht? Verslag van een onderzoek naar het gebruik van de interventie 'Wijzer met Welder' door een groep leden van CNV PubliekeZaak. Hoofddorp: TNO; 2014. 
12. Groothoff JW, Brouwer S, Bakker RH, Overweg K, Schellekens JMH, Abma F, et al. BIMRA: beoordelen van interventies en meetinstrumenten bij re-integratie naar arbeid: eindrapportage. Groningen: Universitair Medisch Centrum Groningen/Rijksuniversiteit Groningen; 2008.

13. Rijk A de. Arbeidsre-integratie blijft mensenwerk. Tijdschr Gezondheidswet. 2018;96(5):208-15.

14. Kulikowski K. Do we all agree on how to measure work engagement? Factorial validity of Utrecht Work Engagement Scale as a standard measurement tool-a literature review. IntJOccup Med Environ Health. 2017;30(2):161-75.

15. Bouwmans C, Krol M, Severens H, Koopmanschap M, Brouwer W, Hakkaart-van Roijen L. The iMTA Productivity
Cost Questionnaire: a standardized instrument for measuring and valuing health-related productivity losses. Value Health. 2015;18(6):753-8.

16. Janssen MF, Pickard AS, Golicki D, Gudex C, Niewada M, Scalone L, et al. Measurement properties of the EQ-5D5L compared to the EQ-5D-3L across eight patient groups: a multi-country study. Qual Life Res. 2013;22(7):1717-27.

17. Schwarzer R, Jerusalem M. Generalized self-efficacy scale. In: Weinman J, Wright S, Johnston M, redactie. Measures in health psychology: a user's portfolio. Causal and control beliefs. Windsor: NFER-NELSON; 1995:35-7. 